\title{
Climatically determined spatial and temporal changes in the biomass of Pinus sp. of Eurasia in the context of the law of the limiting factor
}

\author{
Vladimir Andreevich Usoltsev ${ }^{1,2}$, Walery Zukow ${ }^{3, *}$, Ivan Stepanovich Tsepordey ${ }^{2}$ \\ ${ }^{1}$ Ural State Forest Engineering University, 620100 Yekaterinburg, Sibirskiy Trakt, 37, Russia \\ ${ }^{2}$ Botanical Garden of Ural Branch of RAS, 620144 Yekaterinburg, 8 Marta str., 202a, Russia \\ ${ }^{3}$ Faculty of Earth Sciences and Spatial Management, Nicolaus Copernicus University, str. Lwowska 1, \\ 87-100 Toruń, Poland \\ *corresponding author e-mail: zukow@wp.pl
}

Received: 10 November 2021 / Accepted: 15 December 2021

\begin{abstract}
Forest ecosystems play an essential role in climate stabilization, and the study of influence of climate change on their biomass and carbon depositing is of paramount importance. The objective of this study was (a) to verify the operation of the law of the limiting factor at the transcontinental level when modeling changes in the biomass of trees and stands of the two-needled subgenus Pinus sp. of Eurasia in relation to geographicallydeterminedindicators oftemperaturesandprecipitation, and(b)toshow thepossibilityof usingtheconstructedclimate-conditioned models of tree and stand biomass in predicting temporal changes in tree and stand biomass based on the principle of space-for-time substitution. As a result of the implementation of the principles of the limiting factor and space-for-time substitution, a common pattern has been established on tree and stand levels: in sufficiently moisture-rich climatic zones, an increase in temperature by $1^{\circ} \mathrm{C}$ with a constant amount of precipitation causes an increase in aboveground biomass, and in moisture-deficient zones - its decrease; in warm climatic zones, a decrease in precipitation by $100 \mathrm{~mm}$ at a constant average January temperature causes a decrease in aboveground biomass, and in cold climatic zones - its increase.
\end{abstract}

Keywords: biomass of trees, biomass in stands, database, regression analysis, the principle of space-for-time substitution, the law of the limiting factor, transcontinental level, temperature, precipitation.

\section{Introduction}

Anthropogenic environmental changes affect ecosystems at all levels of the organization (Díaz et al., 2019). Climate change is associated with an increase in global average temperature by $0.76^{\circ} \mathrm{C}$ over the past 150 years, and recent years are the warmest in the entire history of observations (Solomon et al., 2007). Climate forecasts suggest an increase in air temperature, a decrease in precipitation and an increase in the frequency of extreme climatic events; the survival of species will depend on their ability to adapt to longer periods of plant water stress and likely changes in the spectrum of pests and diseases. These conditions in different climatic zones of the Northern Hemisphere will have different effects on the growth of the main forest-forming species (Fischlin et al., 2009).

In functional biogeography, it is assumed that the properties of plants reflect the adaptation of vegetation to changing environmental conditions, including climate (Reichstein et al., 2014). Forest biomass is an integral component in solving the problem of sustainable development (Müller et al., 2015) and is one of the main indicators in climate research (Bojinski et al., 2014). Modern global vegetation models are aimed at implementing adaptive plant reactions in the context of optimality theory (Rosen, 1967; Korzukhin \& Semevsky, 1992). Since the response of 
plants to stress manifests itself in changes in their biomass, it is of interest to know how the biomass and carbon deposition capacity of forests will change due to climate shifts (Franklin et al., 2020; Tautenhahn et al., 2020).

Over the past two decades, airborne laser sensing technology has been intensively used to assess terrestrial biomass, providing highly accurate information about the spatial and temporal characteristics of forests. Due to the ability to penetrate through the thickness of the canopy, laser sensing data representing three-dimensional point clouds give a detailed $3 \mathrm{D}$ picture of the structure of tree morphology (Camarretta et al., 2021; Wagers et al., 2021). This provides great opportunities for assessing the biomass of trees and stands using remote measurements.

A strict and stable allometric ratio (power function) is known between the biomass of a tree and its diameter (simple allometry), or between the biomass of a tree and some mass-forming indicators (multifactorial allometry), and similar allometric equations for different tree species in the world are already in the tens of thousands (Jenkins et al., 2004). Allometric models of tree biomass are particularly relevant when assessing biomass in mixed species stands (Shuman et al., 2011).

In the proposed allometric models sensitive to climate change (He et al., 2021), the prediction of changes in the biomass of trees and stands during climatic shifts is based on the principle of space-for-time substitution (Smolonogov, 1995). J. L. Blois et al. (2013) write: "Viewed broadly, space-for-time substitution encompasses analyses in which contemporary spatial phenomena are used to understand and model temporal processes that are otherwise unobservable, most notably past and future events. Many fields have developed and debated methods relying on spacefor-time substitution, such as ecological chronosequences to study long-term nutrient cycling and plant succession and transfer functions for inferring past environmental changes from geological proxies" (P. 9374).
It is known that the production of plant biomass is limited by a factor that is in minimum or excess in relation to its needs according to the principle of limiting factor (Liebig, 1840; Shelford, 1913). At the polar limit of birch distribution in Siberia, the limiting factor is temperature, but as we move south, the heat deficit decreases and the role of moisture deficiency increases. At the same time, the change of the limiting factor occurs in the subzone of the middle taiga (Fonti, 2020).

The purpose of this study was to test two working hypotheses:

- does the law limiting factor on a transcontinental level in the modeling of changes in the biomass of trees and the forest on the territory of Eurasia in connection with geographically weighted temperature and precipitation, for example, of two-needled subgenus Pinus sp.;

- to show whether the built climate-driven model of biomass of trees and forest stands, sensitive to temperature and precipitation in the territorial gradients can be used to predict changes in biomass temporal gradients based on the principle of spacefor-time substitution.

\section{Material and methods}

From the compiled biomass databases of 15,300 sample trees (Usoltsev, 2020) and 7,500 sample forest stands (Usoltsev, 2010), 3734 Pinus sp. trees (Fig. 1) and 2797 Pinus sp. stands (Fig. 2) were selected (Tables 1 and 2). The harvest data on the biomass of trees were obtained within the ranges of different species. The matrix of biomass data and taxation characteristics was assessed against the main driver variables of mean January temperature (Fig. 1) and precipitation (Fig. 2) taken from World Weather Maps (2007). The use of the maps of winter temperature instead of the average annual one was justified earlier (Usoltsev et al., 2019).

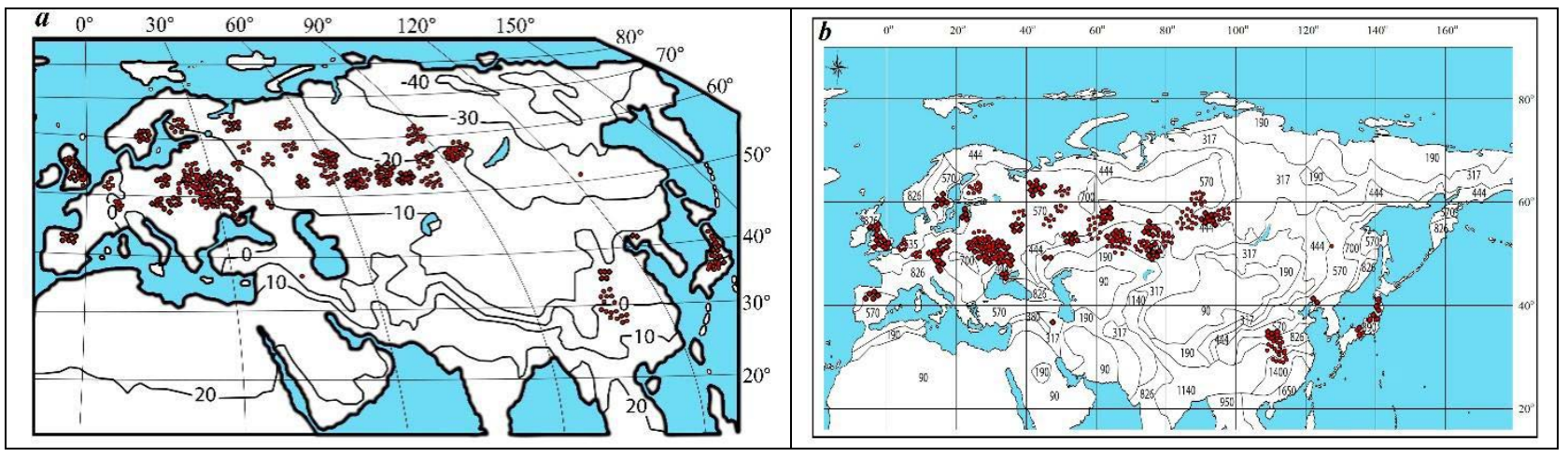

Figure 1. Distribution of 3734 biomass harvest data of Pinus sp. single-trees (kg) on the map of the mean January temperature, ${ }^{\circ} \mathrm{C}(\mathrm{https}: / /$ store.mapsofworld.com/image/cache/data/map_2014/currents-and-temperature-jan-enlarge-900×700.jpg) (a) and on the map of the mean annual precipitation, mm (b) (https://www.eldoradoweather.com/climate/world-maps/world-annual-precip-map.html) (World Weather Maps, 2007) 

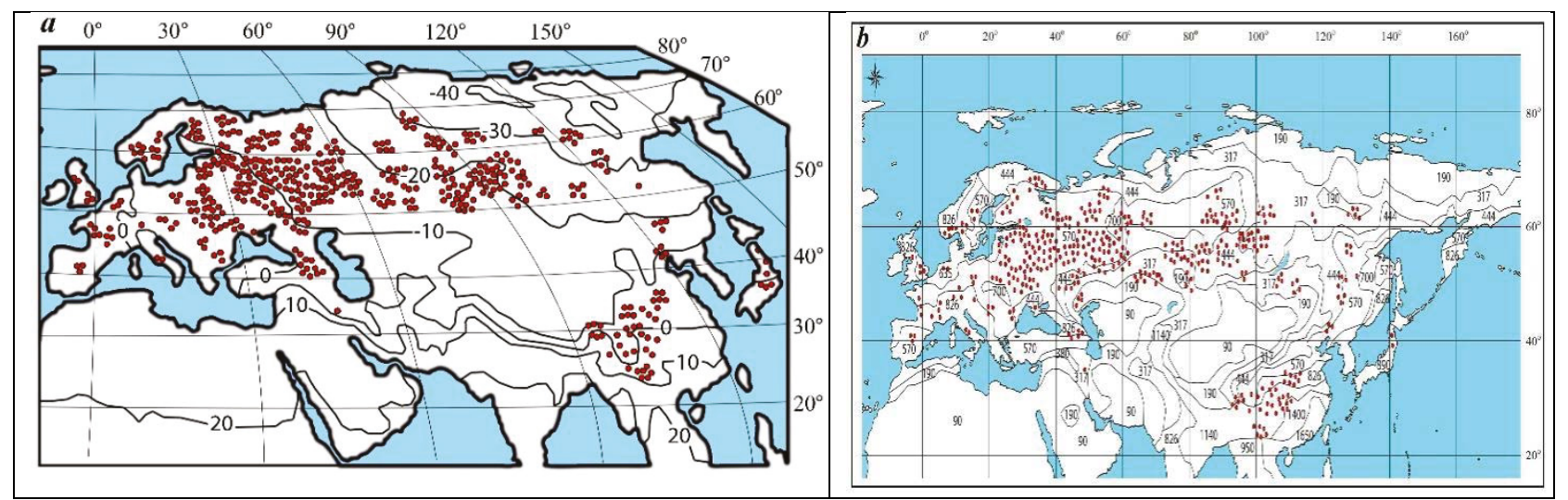

Figure 2. Distribution of 2797 biomass harvest data of Pinus sp. forests (t/ha) on the map of the mean January temperature, ${ }^{\circ} \mathrm{C}$ (https:// store.mapsofworld.com/image/cache/data/map_2014/currents-and-temperature-jan-enlarge-900×700.jpg) (a) and on the map of the mean annual precipitation, mm (b) (https://www.eldoradoweather.com/climate/world-maps/world-annual-precip-map.html) (World Weather Maps, 2007)

Table 1. Statistics of database samples for Pinus single-trees in Eurasia

\begin{tabular}{|l|r|r|r|r|r|}
\hline \multirow{2}{*}{$\begin{array}{c}\text { Statistic } \\
\text { designation }^{(a)}\end{array}$} & \multicolumn{5}{|c|}{ Indices analyzed $^{(b)}$} \\
\cline { 2 - 6 } & $\boldsymbol{H}$ & \multicolumn{1}{c|}{$\boldsymbol{D}$} & $\boldsymbol{D} \boldsymbol{c r}$ & $\boldsymbol{p b a z}$ & $\boldsymbol{P}_{\text {tree }}$ \\
\hline Mean & 12.9 & 14.0 & 2.3 & 399.4 & 102.0 \\
\hline Min & 0.7 & 0.3 & 0.2 & 214.1 & 0.04 \\
\hline Max & 36.6 & 60.9 & 13.9 & 925.2 & 1785.2 \\
\hline SD & 7.1 & 9.5 & 1.3 & 91.9 & 183.5 \\
\hline CV, \% & 55.4 & 68.4 & 56.9 & 23.0 & 179.8 \\
\hline $\mathrm{n}$ & 3734 & 3734 & 2128 & 1482 & 3636 \\
\hline
\end{tabular}

(a) Mean is mean value; Min is minimum value; Max is maximum value; $\mathrm{SD}$ is standard deviation; $\mathrm{CV}$ is coefficient of variation; $n$ is number of observations.

${ }^{(b)} \mathrm{H}$ is tree height, $\mathrm{m} ; \mathrm{D}$ is stem diameter at breast height, cM; $D c r$ is crown width, $\mathrm{m}$; pbaz $P_{\text {tree }}$ is aboveground biomass in a completely dry condition, $\mathrm{kg}$.

Table 2. Statistics of database samples for Pinus forests in Eurasia

\begin{tabular}{|l|r|r|r|r|c|}
\hline \multirow{2}{*}{$\begin{array}{c}\text { Statistic } \\
\text { designation }\end{array}$} & \multicolumn{5}{|c|}{ Indices analyzed $^{(\mathrm{a})}$} \\
\cline { 2 - 6 } & $\boldsymbol{A}$ & $\boldsymbol{N}$ & $\boldsymbol{V}$ & $\boldsymbol{P}_{\text {stand }}$ & $\boldsymbol{Z}_{\text {stand }}$ \\
\hline Mean & 53 & 3.7 & 188.3 & 98.5 & 6.8 \\
\hline Min & 4 & 0.05 & 1.3 & 2.0 & 0.37 \\
\hline Max & 383 & 145.0 & 700.0 & 358.4 & 21.1 \\
\hline SD & 39.8 & 7.8 & 132.6 & 63.9 & 3.8 \\
\hline CV, \% & 75.5 & 209.9 & 70.4 & 64.9 & 56.3 \\
\hline $\mathrm{n}$ & 2797 & 2797 & 2674 & 2679 & 829 \\
\hline
\end{tabular}

(a) $\mathrm{A}$ is stand age, years; $N$ is tree number, 1000 per ha; $V$ is stem volume, $\mathrm{m}^{3} /$ ha; $P_{\text {stand }}$ is aboveground stand biomass in dry condition, $\mathrm{t}$ per ha; $Z_{\text {stand }}$ is annual aboveground net primary production (NPP), t per ha.

In accordance with the purposes of the study, data analysis and model construction is performed at two levels: of both individual trees and stands. At the tree level, it is planned to study two types of models: those designed for lidar airborne sensing and for ground-based mensuration. At the stand level, it is also planned to study models of two types, namely, at the sublevels of biomass and NPP of stands.

The harvest data on the aboveground biomass of trees and stands, the characteristics of which are given in Tables 1 and 2, were processed by the method of multiple regression analysis using software Statgraphics (http://www. statgraphics.com/).

\section{Results}

Regression models for Pinus sp. sensitive to climate change are calculated at the four mentioned levels:

- the tree-level model designed for estimating biomass by means of lidar sensing

$\ln P_{\text {tree }}=20.0555+1.2104(\ln D c r)+1.9199(\ln H)$ $-6.9317[\ln (T+50)]-3.4718(\ln P R)+1.0972[\ln (T+50)] \cdot(\ln P R)$; $\operatorname{adj} R^{2}=0.925 ; \mathrm{SE}=0.49$;

- the tree-level model designed to estimate biomass by ground-based taxation

$\ln P_{\text {tree }}=1.5852+1.6469(\ln D)-0.1259(\ln H)+0.2151(\ln D)$ $(\ln \mathrm{H})+0.5356 \ln ($ pbas $)-1.8920[\ln (T+50)]-1.2091(\ln P R)$ $+0.3561[\ln (T+50)] \cdot(\ln P R) ; \operatorname{adj}^{2}=0.990$;

$\mathrm{SE}=0.20$;

- the stand-level model designed to assess aboveground biomass

$\ln P_{\text {stand }}=5.6372+0.0293(\ln A)-0.0030(\ln N)+0.8123(\ln V)$

- 1.5514[ $\ln (T+50)]-0.9366(\ln P R)+0.2680[\ln (T+50)] \cdot(\ln P R)$;

$\operatorname{adj} R^{2}=0.949 ; \mathrm{SE}=0.18$;

- the stand-level model designed to evaluate aboveground net primary production (NPP) 
$\ln Z_{\text {stand }}=10.1713+0.0863(\ln A)(\ln N)+0.5099\left(\ln P_{\text {stand }}\right)$ $-3.6789[\ln (T+50)]-2.1470(\ln P R)+0.7005[\ln (T+50)] \cdot(\ln P R)$; $\operatorname{adjR}^{2}=0.522 ; \mathrm{SE}=0.43$.

In (1)-(4): $T$ is average January temperature, ${ }^{\circ} \mathrm{C} ; P R$ is average annual precipitation, $\mathrm{mm} ;[\ln (T+50)] \cdot(\ln P R)$ is combined variable that characterizes the combined effect of temperature and precipitation. The abbreviation $\operatorname{adj}^{2}$ is a coefficient of determination adjusted for the number of parameters; SE - equation standard error.

Since the average temperature of January in high latitudes has a negative value, for its logarithmic transformation in the models (1)-(4), it is modified to the form $(T+50)$. Regression coefficients for all the biomass components in models (1)-(4) are significant at the level of $\mathrm{p}<0.001$. Models (1)-(4) are valid within the ranges of independent variables shown in Tables 1 and 2. When calculating models (1)-(4), a correction for the logarithmic transformation was applied (Sprugel, 1983).

The geometric interpretation of models (1)-(4) is presented in the form of 3D pictures of the biomass of trees and stands in relation to temperatures and precipitation (Fig. 3). They are obtained by substituting in (1)-(4) the average values of the independent variables shown in Tables 1 and 2. In Figure 3, we can see that the dependences of the aboveground biomass of trees of the same size, as well as of stands of the same morphological structure, on temperatures and precipitation are described by $3 \mathrm{D}$ propeller-shaped surfaces.

There are some differences between the patterns at the tree and stand levels on the Figure 3 ( 1 and 2) and the Figure 3 (3 and 4) respectively. On the tree level, in warm regions, as precipitation increases, the biomass increases too, but as it moves to cold regions, it is characterized by the opposite

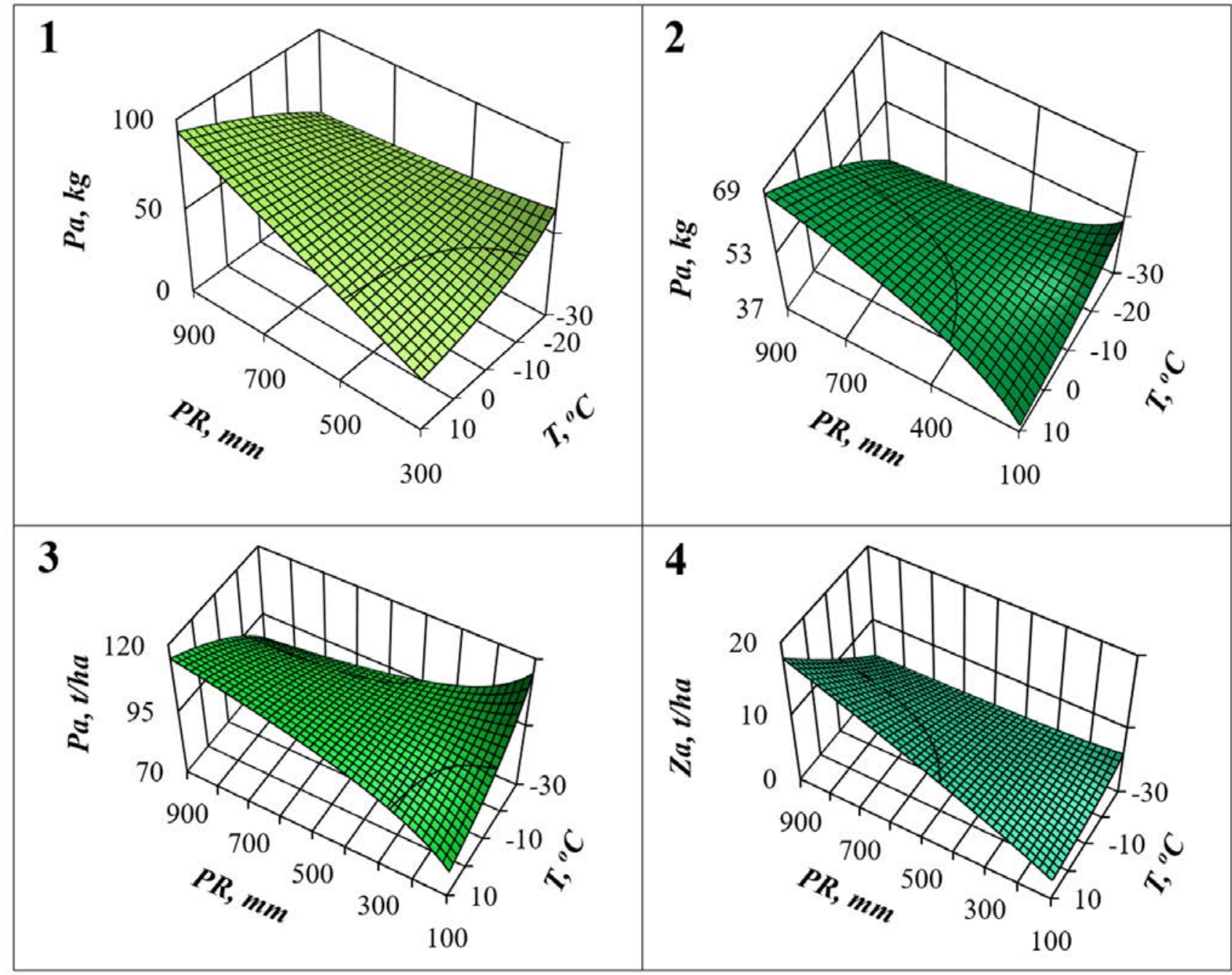

Figure 3. Calculated according to models (1)-(4) changes in aboveground biomass due to the average January temperature (T) and average annual precipitation $(P R): 1$ - according to the tree-level model (1) designed for estimating biomass by means of lidar sensing; 2 - according to the tree-level model (2) designed to estimate biomass by ground-based taxation; 3 - according to the stand-level model (3) designed to assess aboveground biomass; 4 - according to the stand-level model (4) designed to evaluate aboveground NPP 
trend. On the stand level, in warm regions, as precipitation increases, the biomass increases too, but as it moves to cold regions, it is characterized by the opposite trend. On the other hand, on the tree level, as the temperature increases in humid regions, the biomass increases, but as the transition to dry conditions begins to decrease. Correspondingly, on the stand level, as the temperature increases in humid regions, the biomass and NPP increase too, but as the transition to dry conditions they are characterized by the opposite trend.

Let's consider the described patterns in a different perspective, realizing the concept of space-for-time substitution and the principle of "What happens if ...?". In other words, what will be the reaction of the biomass of trees and stands if, with the constancy of territorial gradients of temperature and precipitation, we assume an increase in temperature over time by $1^{\circ} \mathrm{C}$ and a reduction in annual precipitation by $100 \mathrm{~mm}$. Taking the first derivatives from the two-factor surfaces presented in Figure 3, we obtained the regularities of biomass changes at the specified temperature and precipitation increments (Figs 4 and 5).

With possible temperature increase by $1^{\circ} \mathrm{C}$ at different territorial temperature levels, denoted as $-30 \Delta \ldots+10 \Delta$, in conditions of sufficient moisture, Figure $4(1,2)$ shows an increase in tree biomass by $2-3 \%$ and $1 \%$ (red area) in cold and warm zones, respectively, and in conditions of insufficient moisture, tree biomass decreases by $2-3 \%$ and $1-2 \%$ (blue area) in cold and warm zones, respectively. At the level of stands (Fig. $4(3,4)$ ) in conditions of sufficient

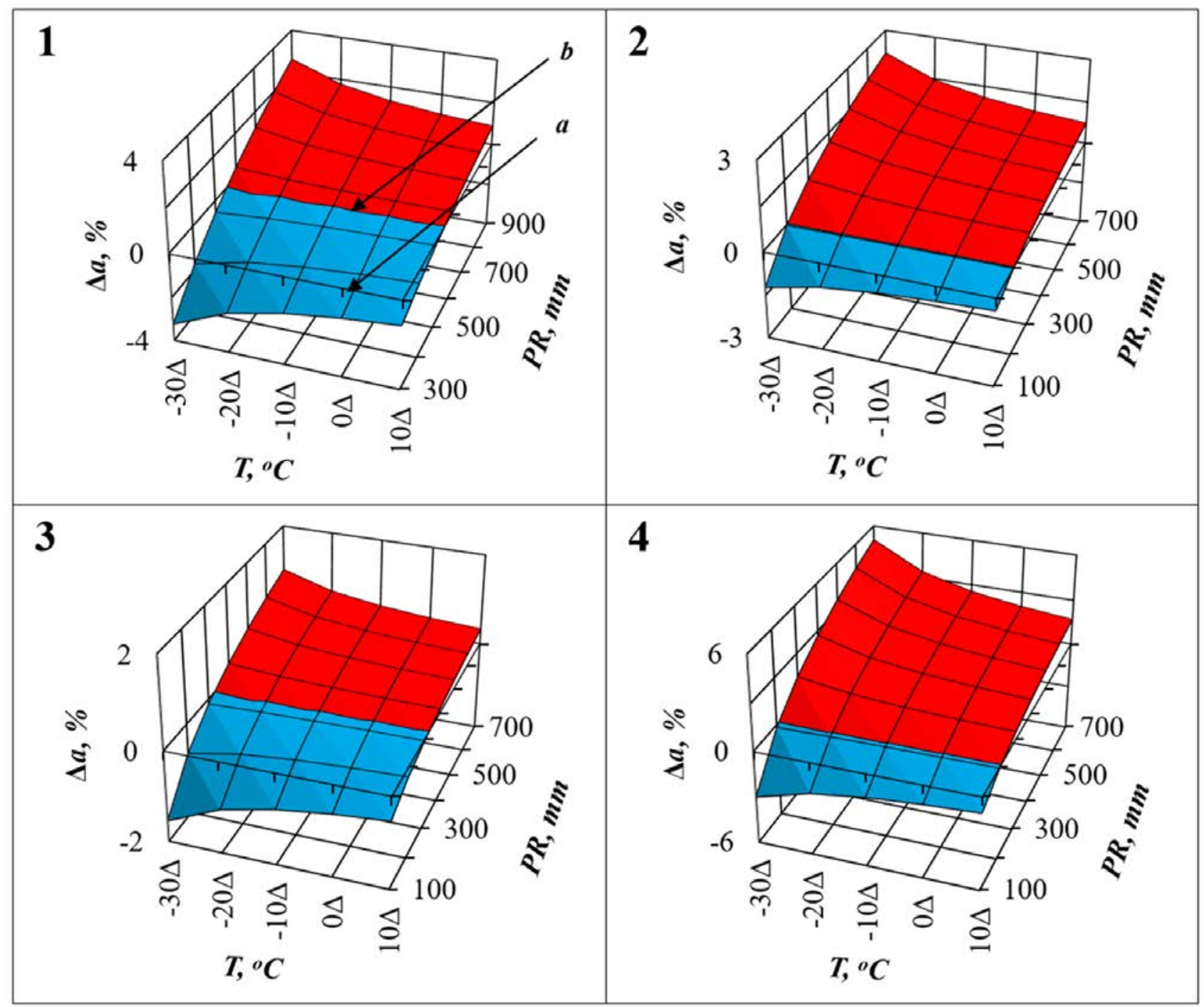

Figure 4. The change in the biomass of trees and stands with an increase in temperature by $1^{\circ} \mathrm{C}$ due to the expected climate change at different territorial levels of temperatures and precipitation. Here and further: numbers from 1 to 4 correspond to the numbers of models (1)-(4) and the numbers shown in Fig. 3; (a) - is the plane corresponding to zero change in biomass with an expected temperature increase by $1^{\circ} \mathrm{C} ;(b)$ - is the line of demarcation of positive and negative changes in biomass with an expected temperature increase by $1^{\circ} \mathrm{C}$ 
moisture, there is an increase in biomass and NPP by $1-5 \%$ and $1-2 \%$ (red area) in cold and warm zones, respectively, and in conditions of insufficient moisture, there is a decrease in biomass and NPP by $1.5-3 \%$ and $0.5-2 \%$ (blue area) in cold and warm zones, respectively.

With possible reduction in annual precipitation by 100 $\mathrm{mm}$ at different territorial precipitation levels, designated as $-400 \Delta \ldots-900 \Delta$, under conditions of sufficient moisture, Figure $5(1,2)$ shows an increase in tree biomass by $3 \%$ (red area) and a decrease by $7 \%$ (blue area) in cold and warm zones, respectively, and in conditions of insufficient moisture, the biomass of trees increases by 3-4\% (red area) and decreases by $8-35 \%$ (blue area) in cold and warm zones, respectively. At the level of stands (Fig. $5(3,4)$ ) under conditions of sufficient moisture, there is an increase in biomass and NPP by $2-3 \%$ (red area) and a decrease by $3-13 \%$ (blue area) in cold and warm zones, respectively, and in conditions of insufficient moisture, there is an increase in biomass and NPP by $4-5 \%$ (red area) and a decrease by $5-25 \%$ (blue area) in cold and warm zones, respectively.

\section{Discussion}

In the study on European forests, there was no statistically significant effect of temperature and precipitation on the biomass of trees (Forrester et al., 2017). In general, climatic indicators explain in many cases a statistically insignificant proportion of the variability of the biomass of stands (Stegen et al., 2011). Our research has proved the opposite and statistically reliable patterns. However, the established patterns of changes in the biomass of trees and stands with the expected climatic shifts (Figs 3, 4 and 5) are hypothetical. They reflect the long-term adaptive responses of forest trees and stands to regional climatic conditions and do not take into account the rapid trends of current environmental changes, which impose serious restrictions on the ability of forests to adapt to new climatic conditions (Dussarrat et al., 2021). Ecosystem responses to anthropogenic stresses are classified as various manifestations of collapse. The smooth course of stress pressure leaves the ecosystem a chance to adapt, but the most dangerous are sharp fluctuations in

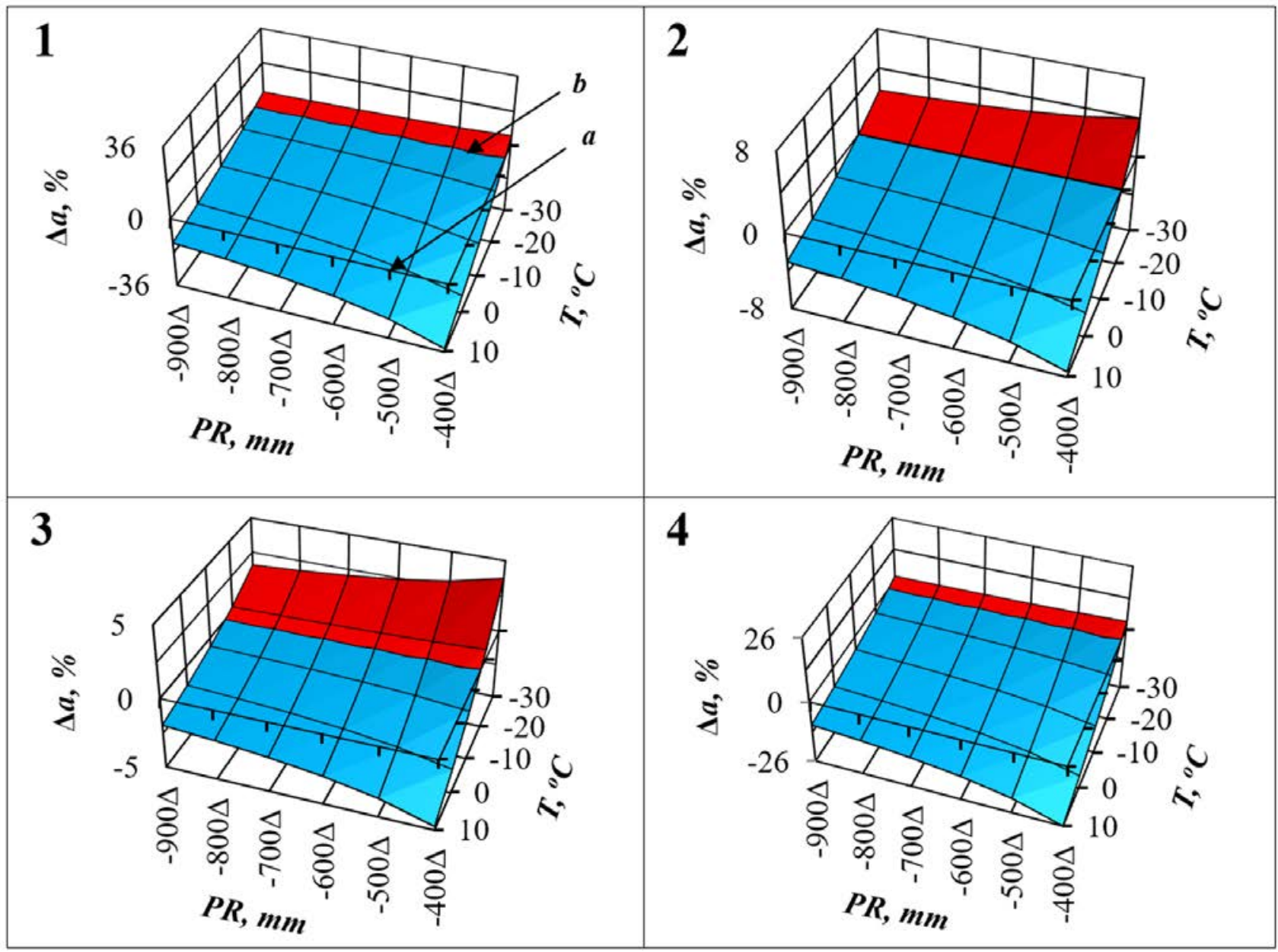

Figure 5. Changes in the biomass of trees and stands with a decrease in precipitation by $100 \mathrm{~mm}$ due to the expected climate change at different territorial levels of temperatures and precipitation 
temperatures and precipitation, which potentially cause the death of the ecosystem (Bjorkman et al., 2018; Bergstrom et al., 2021).

In the space-temporal forecasting of the environmental consequences of climate change, large uncertainties are created by incomplete and poor-quality precipitation data, which, in particular, have insufficient spatial content (Dai, 2011; Sheffield et al., 2012; Trenberth et al., 2014; Le Vine et al., 2016; Dai \& Zhao, 2017; Sun et al., 2018). The available precipitation data give rise to significant uncertainties when gaps are filled with some statistical data on climatology (Dai \& Zhao, 2017). Thus, the cumulative effect of uncertainties in the assessment of topographic variables (Daly et al., 2017), the rough resolution of the results of climate models (Maraun et al., 2010) and the poor quality of precipitation data lead to large uncertainties in assessing the effects of climate change on forest ecosystems.

We used the existing changes in the biomass of trees and stands in territorial climatic gradients to predict its possible changes in the assumed temporal gradients of temperature and precipitation. However, the fundamental assumption that spatial relationships between climate and biomass can be used to predict temporal trajectories of biological productivity in a changing climate remains largely untested (Veloz et al., 2012). The success of the application of the theory of space-for-time substitution in plant ecology depends on the extent to which the ecological conditions determining the properties of plants in territorial gradients correspond to the future ecological conditions determining the properties of plants in a temporal gradient (Bjorkman et al., 2018; Bergstrom et al., 2021). Nevertheless, when there is no other way to study ecosystem processes in the future, the method of space-for-time substitution is still quite an acceptable alternative. And this alternative is convincingly shown in our work in models of four levels, both for trees and for stands on the example of the subgenus Pinus sp.

\section{Conclusion}

The main achievement of our research is that the effect of the law of the limiting factor is shown not only in relation to individual trees, but also in relation to stands. Moreover, this action is illustrated for the first time by the example of the subgenus Pinus sp. in trans-Eurasian climatic gradients, both spatial and temporal, which can be used in the development of strategies for managing the carbon depositing capacity of forests.

\section{References}

Bergstrom D.M., Wienecke B.C., van den Hoff J., Hughes L., Lindenmayer D.B., Ainsworth T.D., Baker C.M., Bland L., Bowman D.M.J.S., Brooks S.T., Canadell J.G., Constable A.J., Dafforn K.A., Depledge M.H., Dickson C.R., Duke N.C., Helmstedt K.J., Holz A., Johnson C.R., McGeoch M.A., Melbourne-Thomas J., Morgain R., Nicholson E., Prober S.M., Raymond B., Ritchie E.G., Robinson S.A., Ruthrof K.X., Setterfield S.A., Sgrò C.M., Stark J.S., Travers T., Trebilco R., Ward D.F.L., Wardle G.M., Williams K.J., Zylstra P.J. \& Shaw J.D., 2021, Combating ecosystem collapse from the tropics to the Antarctic. Global Change Biology 27: 1-12.

Bjorkman A.D., Myers-Smith I.H., Elmendorf S.C., Normand S., Rüger N., Beck P.S.A., Blach-Overgaard A., Blok D., Cornelissen J.H.C., Forbes B.C., Georges D., Goetz S.J., Guay K.C., Henry G.H.R., RisLambers J.H., Hollister R.D., Karger D.N., Kattge J., Manning P., Prevéy J.S., Rixen C., Schaepman-Strub G., Thomas H.J.D., Vellend M., Wilmking M., Wipf S., Carbognani M., Hermanutz L., Lévesque E., Molau U., Petraglia A., Soudzilovskaia N.A., Spasojevic M.J., Tomaselli M., Vowles T., Alatalo J.M., Alexander H.D., Anadon-Rosell A., Angers-Blondin S., te Beest M., Berner L., Björk R.G., Buchwal A., Buras A., Christie K., Cooper E.J., Dullinger S., Elberling B., Eskelinen A., Frei E.R., Grau O., Grogan P., Hallinger M., Harper K.A., Heijmans M.M.P.D., Hudson J., Hülber K., Iturrate-Garcia M., Iversen C.M., Jaroszynska F., Johnstone J.F., Jørgensen R.H., Kaarlejärvi E., Klady R., Kuleza S., Kulonen A., Lamarque L.J., Lantz T., Little C.J., Speed J.D.M., Michelsen A., Milbau A., Nabe-Nielsen J., Nielsen S.S., Ninot J.M., Oberbauer S.F., Olofsson J., Onipchenko V.G., Rumpf S.B., Semenchuk P., Shetti R., Collier L.S., Street L.E., Suding K.N., Tape K.D., Trant A., Treier U.A., Tremblay J.-P., Tremblay M., Venn S., Weijers S., Zamin T., Boulanger-Lapointe N., Gould W.A., Hik D.S., Hofgaard A., Jónsdóttir I.S., Jorgenson J., Klein J., Magnusson B., Tweedie C., Wookey P.A., Bahn M., Blonder B., van Bodegom P.M., Bond-Lamberty B., Campetella G., Cerabolini B.E.L., Chapin III F.S., Cornwell W.K., Craine J., Dainese M., de Vries F.T., Díaz S., Enquist B.J., Green W., Milla R., Niinemets Ü., Onoda Y., Ordoñez J.C., Ozinga W.A., Penuelas J., Poorter H., Poschlod P., Reich P.B., Sandel B., Schamp B., Sheremetev S. \& Weiher E., 2018, Plant functional trait change across a warming tundra biome. Nature 562: 57-80.

Blois J.L., Williams J.W., Fitzpatrick M.C., Jackson S.T. \& Ferrier S., 2013, Space can substitute for time in predicting climate-change effects on biodiversity. Proceedings of the National Academy of Sciences of the United States of America 110 (23): 9374-9379. 
Bojinski S., Verstraete M., Peterson T.C., Richter C., Simmons A. \& Zemp M., 2014, The concept of essential climate variables in support of climate research, applications, and policy. Bulletin of the American Meteorological Society 95 (9): 1431-1443.

Camarretta N., Harrison P.A., Lucieer A., Potts B.M., Davidson N. \& Hunt M., 2021, Handheld laser scanning detects spatiotemporal differences in the development of structural traits among species in restoration plantings. Remote Sensing 13: Article 1706. https://doi.org/10.3390/ rs13091706

Dai A., 2011, Drought under global warming: a review. WIREs Climate Change 2: 45-65.

Dai A. \& Zhao T., 2017, Uncertainties in historical changes and future projections of drought. Part I: Estimates of historical drought changes. Climatic Change 144(3): 519-533.

Daly C., Slater M.E., Roberti J.A., Laseter S.H. \& Swift L.W., 2017, High resolution precipitation mapping in a mountainous watershed: ground truth for evaluating uncertainty in a national precipitation dataset. International Journal of Climatology 37: 124-137.

Díaz S., Settele J., Brondizio E.S., Ngo H.T., Agard J., Arneth A., Balvanera P., Brauman K.A, Butchart S.H.M., Chan K.M.A., Lucas A.G., Ichii K., Liu J., Subramanian S.M., Midgley G.F., Miloslavich P., Molnár Z., Obura D., Pfaff A., Polasky S., Purvis A., Razzaque J., Reyers B., Chowdhury R.R., Shin Y.J., Visseren-Hamakers I., Willis K.J. \& Zayas C.N., 2019, Pervasive human-driven decline of life on Earth points to the need for transformative change. Science 366: Article 1327.

Dussarrat T., Decros G., Díaz F.P., Gibon Y., Latorre C., Rolin D., Gutiérrez R.A., Pétriacq P., 2021, Another tale from the harsh world: How plants adapt to extreme environments. Annual Plant Reviews 4: 551-604.

Fischlin A., Ayres M., Karnosky D., Kellomäki S., Louman B., Ong C., Plattner G.K., Santoso H., Thompson I., Booth T.H., Marcar N., Scholes B., Swanston C. \& Zamolodchikov D., 2009, Future environmental impacts and vulnerabilities, [in:] R. Seppälä, A. Buck, P. Katila (eds), Adaptation of forests and people to climate change: a global assessment report. IUFRO World Series, Vol. 22: 53-100.

Fonti M.V., 2020, Climatic signal in the parameters of annual rings (wood density, anatomical structure and isotopic composition) of coniferous and deciduous tree species in various natural and climatic zones of Eurasia: Diss. ... Doct. Biol. Sci.: 03.02.08. Krasnoyarsk, Siberian Federal University, 45 pp. https://research.sfu-kras.ru/ sites/research.sfu-kras.ru/files/Avtoreferat_Fonti.pdf (in Russian).
Forrester D.I., Tachauer I.H., Annighöefer P., Barbeito I.G., Pretzsch H., Ruiz-Peinado R., Stark H., Vacchiano G., Zlatanov T., Chakraborty T., Saha S. \& Sileshi G.W., 2017, Generalized biomass and leaf area allometric equations for European tree species incorporating stand structure, tree age and climate. Forest Ecology and Management 396: 160-175.

Franklin O., Harrison S.P., Dewar R., Farrior C.E., Brännström Å., Dieckmann U., Pietsch S., Falster D., Cramer W., Loreau M., Wang H., Mäkelä A., Rebel K.T., Meron E., Schymanski S.J., Rovenskaya E., Stocker B.D., Zaehle S., Manzoni S., van Oijen M., Wright I.J., Ciais P., van Bodegom P.M., Peñuelas J., Hofhansl F., Terrer C., Soudzilovskaia N.A., Midgley G. \& Prentice I.C., 2020, Organizing principles for vegetation dynamics. Nature Plants 6: 444-453.

He X., Lei X.-D. \& Dong Li-Hu, 2021, How large is the difference in large-scale forest biomass estimations based on new climate-modified stand biomass models? Ecological Indicators 126: Article 107569.

Jenkins J.C., Chojnacky D.C., Heath L.S. \& Birdsey R.A., 2004, Comprehensive database of diameter-based regressions for North American tree species. USDA Forest Service Northeast-ern Research Station. General Technical Report NE-319. 45 pp.

Korzukhin M.D. \& Semevsky F.N., 1992, Synecology of the forest. Hydrometeoizdat, St. Petersburg, 192 pp. (in Russian).

LeVine N., Butler A., McIntyre N. \& Jackson C., 2016, Diagnosing hydrological limitations of a land surface model: application of JULES to a deep-groundwater chalk basin. Hydrology and Earth System Sciences Discussions 20(1): 143-159.

Liebig J., 1840, Die organische Chemie in ihrer Anwendung auf Agricultur und Physiologie. Verlag Vieweg, Braunschweig. In: Deutsches Textarchiv <http:// www.deutschestextarchiv.de/liebig_agricultur_1840> [Abgerufen am 26.11.2019].

Maraun D., Wetterhall F., Ireson A.M., Chandler R.E., Kendon E.J., Widmann M., Brienen S., Rust H.W., Sauter T., Themeß M., Venema V.K.C., Chun K.P., Goodess C.M., Jones R.G., Onof C., Vrac M. \& Thiele-Eich I., 2010, Precipitation downscaling under climate change: recent developments to bridge the gap between dynamical models and the end user. Reviews of Geophysics 48(3): RG3003.

Müller A., Weigelt J., Götz A., Schmidt O., Alva I.L., Matuschke I., Ehling U. \& Beringer T., 2015, The role of biomass in the sustainable development goals: A reality check and governance implications. IASS Working Paper. Institute for Advanced Sustainability Studies, Potsdam, 36 pp. 
Reichstein M., Bahn M., Mahecha M.D., Kattge J. \& Baldocchi D.D., 2014, Linking plant and ecosystem functional biogeography. Proceedings of the National Academy of Sciences USA 111: Article 201216065.

Rosen R., 1967, Optimality principles in biology. Butterworths, London. 198 pp.

Sheffield J., Wood E.F. \& Roderick M.L., 2012, Little change in global drought over the past 60 years. Nature 491(7424): 435-438.

Shelford V.E., 1913, Animal communities in temperate America as illustrated in the Chicago region: a study in animal ecology. Iss. 5. Part 1. Pub. for the Geographic Society of Chicago by the University of Chicago Press, $362 \mathrm{pp}$.

Shuman J.K., Shugart H.H., \& O’Halloran T.L., 2011, Sensitivity of Siberian larch forests to climate change. Global Change Biology 2: 2370-2384.

Smolonogov E.P., 1995, Forest formation process and genetic classification of forest types. Lesa Urala I Khozyaistvo $\mathrm{v}$ nikh (Forests of the Urals and Their Management) 18: 43-58 (in Russian). https://elar.usfeu. ru/bitstream/123456789/4453/1/lesa_urala_18_03.pdf

Solomon S., Qin D., Manning M., Chen Z., Marquis M., Avery K., Tignor M.M.B., LeRoy Miller Jr. H., 2007, Climate change 2007: The physical science basis. Contribution of Working Group I to the Fourth Assessment Report of the International Panel on Climate Change. Cambridge University Press.

Sprugel D.G., 1983, Correcting for bias in log-transformed allometric equations. Ecology 64: 209-210.

Stegen J.C., Swenson N.G., Enquist B.J., White E.P., Phillips O.L., Jorgensen P.M., Weiser M.D., Mendoza A.M. \& Vargas P.N., 2011, Variation in above-ground forest biomass across broad climatic gradients. Global Ecology and Biogeography 20 (5): 744-754.

Sun Q., Miao C., Duan Q., Ashouri H., Sorooshian S. \& Hsu K.-L., 2018, A review of global precipitation data sets: Data sources, estimation, and intercomparisons. Reviews of Geophysics 56: 79-107. https://doi.org/10.1002 /2017RG000574
Tautenhahn S., Migliavacca M. \& Kattge J., 2020, News on intra-specific trait variation, species sorting, and optimality theory for functional biogeography and beyond. New Phytologist 228: 6-10.

Trenberth K.E., Dai A., van der Schrier G., Jones P.D., Barichivich J., Briffa K.R. \& Sheffield J., 2014, Global warming and changes in drought. Nature Climate Change 4: 17-22.

Usoltsev V.A., 2010, Eurasian forest biomass and primary production data. Yekaterinburg, Ural Branch of Russian Academy of Sciences, 574 p. DOI: 10.13140/ RG.2.2.35234.17605.http://elar.usfeu.ru/handle/ $123456789 / 2606$

Usoltsev V.A., 2020, Single-tree biomass data for remote sensing and ground measuring of Eurasian forests: digital version. The second edition, enlarged. Yekaterinburg, Ural State Forest Engineering University; Botanical Garden, Ural Branch of Russian Academy of Sciences. https://elar. usfeu.ru/bitstream/123456789/9647/2/Base1_v2_ob.pdf Usoltsev V., Piernik A., Osmirko A., Tsepordey I., Chasovskikh V. \& Zukow W., 2019, Forest stand biomass of Picea spp.: an additive model that may be related to climate and civilisational changes. Bulletin of Geography. Socio-Economic Series 45(45): 133-147. http://dx.doi. $\operatorname{org} / 10.1515 / 18860$

Veloz S., Williams J.W., Blois J.L., He F., Otto-Bliesner B. \& Liu Z., 2012, No-analog climates and shifting realized niches during the late Quaternary: Implications for 21 st-century predictions by species distribution models. Global Change Biology 18: 1698-1713.

Wagers S., Castilla G., Filiatrault M. \& Sanchez-Azofeifa G.A., 2021, Using TLS-measured tree attributes to estimate above ground biomass in small black spruce trees. Forests 12: 1521. https://doi.org/10.3390/f12111521

World Weather Maps, 2007. https://www.mapsofworld.com/ referrals/weather 